Pakistan Journal of Social Sciences 8 (1): 8-12, 2011

ISSN: $1683-8831$

(C) Medwell Journals, 2011

\title{
Strategic Development Financing Mix and Economic Growth in Nigeria
}

\author{
${ }^{1}$ Adesoye A. Bolaji, ${ }^{1}$ Maku E. Olukayode and ${ }^{2}$ Atanda Akinwande AbdulMaliq \\ ${ }^{1}$ Department of Economics, Olabisi Onabanjo University, \\ Ago-Iwoye, Ogun State, Nigeria \\ ${ }^{2}$ Strategic Research Unit, Datatric Research Consulting, P.O. Box 51, \\ Dugbe Ibadan, Oyo State, Nigeria
}

\begin{abstract}
The development of the economy has been a major concern of most developing nations such as Nigeria in the provision of infrastructural facilitie and developmental projects that have the potentials of enhancing the standard of living of the citizens and national outputs. But these objectives can not be achieved without adequate source of developmental funds. As a result of various source options of developmental financing this study examined the effect of debt financing mix on economic growth and development in Nigeria strategically from a decade after independence 1970-2007 fiscal years. Major debt financing options were considered in the analysis of this study and the long-run relationship between selected debts financing mix and economic growth proxy as Real Gross Domestic Product (RGDP) was established through the Augmented Engle Granger (AEG) Cointegration test. The entire time series variables data regressed-treasury bill, development stocks, treasury certificate and bond, multilateral debt source in ternational lending clubs and real gross domestic product-were found stationary at first difference excluding series on international lending clubs which was found explosive. The estimated cointegrated regression model formulated revealed the best economic friendly debts financing mix to achieved major macroeconomic targets of the governments. Strategic policy recommendations were proffered based on the findings emanated from the study.
\end{abstract}

Key words: Domestic debt, external debt, economic growth, developmental finance, unit root, co-integration

\section{INTRODUCTION}

Government, today plays a great and expanding role in any national economy. This is in fact more important in developing countries where the government has to initiate and promote economic development. One of the most crucial issues in relation to the promotion of economic development is the issues of development financing. Government therefore directly or indirectly mobilizes long-term funds for the development aspirations of the nation. The quantum of these resource flows usually determines the level and pace of development attainable by the country concerned.

Development financing mix of the Nigeria economy can broadly be categorised into external and internal sources. These can further be classified into debt and non-debt. The non-debt sources include public and private savings and gains from international trade. Others include direct foreign investment, foreign aids and grants. The debt related sources include treasury bonds, development loan stocks and loans from bilateral, multilateral and international capital market sources.
In the 1950s, Nigeria did not have the need to borrow much from abroad; substantial earnings from export of agricultural produce couple with external assistance (grants) made external borrowing unnecessary. However, in the 1960s, shortage of foreign exchange became one of the bottlenecks to national economic development resulting from declining terms of trade and depletion of the huge foreign exchange reserves accumulated during the boom period of agricultural exports. The trend observed in the Nigerian development financing mix between the early 1980s and the mid-1990s reflected the country's unsteady fortunes arising from fluctuations in international oil prices.

It is evident from recent trends in the Nigeria economy that the low level of investment relative to the volume required to attain sustainable growth rate is indicative of the efforts needed to mobilize both domestic savings and non-debt development financing. The Nigerian economy however, faces a more difficult and daunting task in this regard. Domestic savings in Nigeria have been low and are likely to remain so. The capacity to generate large volume of foreign exchange from exports is

Corresponding Author: Adesoye A. Bolaji, Department of Economics, Olabisi Onabanjo University, Ago-Iwoye, Ogun State, Nigeria 
likely to remain low for as long as the country remains dependent on primary commodities. Recourse to large-scale Official Development Assistance does not appear to be a realistic option. Aids fatigue and fiscal pressures coupled with recession in donor countries are making it more difficult for developing countries like Nigeria to attract adequate Official Development Assistance (ODA) finance flows (World Bank, 2001). From the forgoing, the main objective of this study is to examine the impact of various debts financing mix on the Nigerian economic growth. This is to establish the long-run effect of debt financing mix adopted for structural development in achieving the prime targeted macroeconomic goals in Nigeria.

Relatively little analytical or empirical research has been done on development financing mix in Nigeria. The only recognized studies in this area are those carried out by Ariyo (1999) and Oyejide (1999). Both sudies made use of less analytical and empirical methodology. This study employed a disaggregated methodology approach in analyzing the effect of debt financing mix on economic performance in Nigeria. The financing of economic development has always posed a problem for the LDCS and it is a major constraint on potential growth and economic dynamism. Government therefore harnesses both domestic and international sources for the financing of development. Ariyo (2006) classified developing financing sources available to SSA countries into four namely: the gross national savings (public savings, private savings and current account balance); Foreign Direct Investment; Foreign aid and Debt (domestic or external). Furthermore, researcher stated that to appreciate the relevance of this categorization, it is necessary to analyze the nature and implications of debt and non-debt development financing sources on economic performance. Debt represents funds with fixed contractual financial obligations to which the resources of a nation might be pledged as collateral. To cope adequately in the long run, a nation's debt service capacity must grow at a rate not less than the growth rate of its debt burden.

\section{DETERMINANTS OF FINANCING FLOWS}

Much has been documented in providing empirical explanation of the determinant of financing inflows to developing countries some of which are reviewed as follows. Blejer, Khan and Lim found that in a repressed financial market (which is the hallmark of most developing economies including Nigeria); credit policy affects investment directly, since credits are allocated to firms with access to preferential interest rate mechanism. With respect to fiscal policy, it is clear from empirical findings that high fiscal deficits increase interest rates or reduces the availability of credit to the private sector thus crowding out private investment. Taylor (1997) posited that there are two sets of factors affecting development financing flows. The first are country-specific-pull factors, reflecting domestic opportunity and risks. The second sets of determinants of financing flows to developing countries are global-push-factors such as interest rates, stable exchange rate and labour market conditions. Afterwards, Agenor argued that development financing flows are indeed a result of savings〈investment imbalances across countries which result in transfer of real resources through trade or current account transactions.

Financing flows also respond to economic fundamentals, official policies and financial markets imperfections. It is however, extremely difficult to assess the impact of these policies and distortions because they overlap, creating both impediments and stimuli to financing flows.

\section{MATERIALS AND METHODS}

There are several empirical methodological approaches by researchers in assessing the impact of debt financing mix on economic growth in Nigeria. Some scholars have used simple verbal assessment of solvency by watching movements in some simple debt indices such as total debt service/GDP ratio; total debt service/export ratio, debt/GDP ratio and debt/export ratio. Likewise for this study the trend data for selected debt financing options and real gross domestic product are shown in the Table 1. While, some other researchers have adopted various econometric techniques.

For the essence of this study, the empirical methodology is formulated based on debt financing classification for Sub Saharan Africa (SSA) given by Ajayi. Therefore, the functional relationship between debt financing mix and economic growth proxy as Real Gross Domestic Product (RDGP) is express as:

$$
\mathrm{RGDP}=\mathrm{f}(\text { Debt financing mix })
$$

Then, the mix of debt financing options being used in Nigeria over the years is proxy as Treasury Bill (TB), Development stocks (DEV), Treasury Certificate and Bond (TCB), Multilateral debt source (MULT) and international lending clubs (CLUB) i.e., Paris and London club. All the domestic and external debt options are regressed on real output of the economy with the inclusion of Inflation rate (INF). Inflation is considered in the analysis because 
Pak. J. Soc. Sci., 8 (1): 8-12, 2011

Table 1: Trend of Real output (RGDP) and debt financing options in Nigeria

\begin{tabular}{|c|c|c|c|c|c|c|c|}
\hline Years & RGDP & T-bill & Dev stock & $\mathrm{TC}$ and $\mathrm{TB}$ & Multilateral & Club debt & INF \\
\hline 1970 & 5205.10 & 556.0 & 299.0 & 299.0 & 37.9 & 136.0 & 13.8 \\
\hline 1971 & 6570.70 & 616.0 & 355.0 & 355.0 & 37.9 & 137.8 & 16.0 \\
\hline 1972 & 7208.30 & 368.6 & 410.8 & 410.8 & 102.1 & 158.1 & 3.2 \\
\hline 1973 & 10990.70 & 401.9 & 392.9 & 392.9 & 107.1 & 150.8 & 5.4 \\
\hline 1974 & 18298.30 & 616.0 & 377.8 & 377.8 & 122.0 & 179.0 & 13.4 \\
\hline 1975 & 20957.00 & 616.0 & 840.5 & 840.5 & 126.0 & 200.7 & 33.9 \\
\hline 1976 & 26656.30 & 616.0 & 1358.9 & 1358.9 & 130.3 & 220.1 & 21.2 \\
\hline 1977 & $106,488.00$ & 691.0 & 1815.7 & 1815.7 & 139.5 & 218.5 & 15.4 \\
\hline 1978 & $100,116.00$ & 816.0 & 2197.7 & 2197.7 & 154.3 & 838.0 & 16.6 \\
\hline 1979 & $108,955.00$ & 2119.0 & 2785.0 & 2785.0 & 163.9 & 1433.7 & 11.8 \\
\hline 1980 & $117,334.00$ & 2119.0 & 3069.0 & 3069.0 & 179.1 & 1576.5 & 9.9 \\
\hline 1981 & $98,594.10$ & 5782.0 & 3353.0 & 3353.0 & 179.5 & 1975.9 & 20.9 \\
\hline 1982 & $93,594.00$ & 9782.0 & 3557.0 & 3557.0 & 530.4 & 7456.1 & 7.7 \\
\hline 1983 & $83,519.60$ & 13476.0 & 3851.0 & 3851.0 & 566.4 & 8761.0 & 23.2 \\
\hline 1984 & $66,462.20$ & 15476.0 & 3783.0 & 3783.0 & 1271.2 & 11804.1 & 39.6 \\
\hline 1985 & $71,368.10$ & 16976.0 & 4319.0 & 4319.0 & 1293.5 & 13890.7 & 5.5 \\
\hline 1986 & $257,784.40$ & 16976.0 & 4808.0 & 4808.0 & 4670.7 & 30170.0 & 5.4 \\
\hline 1987 & $255,997.00$ & 25226.0 & 4909.0 & 4909.0 & 8781.5 & 69972.1 & 10.2 \\
\hline 1988 & $275,409.60$ & 35476.0 & 4759.0 & 4759.0 & 9991.8 & 90431.4 & 38.3 \\
\hline 1989 & $295,090.80$ & 24126.0 & 4629.0 & 15979.0 & 21473.6 & 164069.6 & 40.9 \\
\hline 1990 & $472,648.70$ & 25476.0 & 4402.5 & 24402.5 & 34606.3 & 207982.4 & 7.5 \\
\hline 1991 & $328,644.50$ & 57763.1 & 4221.0 & 24221.0 & 39458.3 & 231289.3 & 13.0 \\
\hline 1992 & $337,288.60$ & 103326.5 & 3961.0 & 22967.5 & 89274.3 & 366620.5 & 44.5 \\
\hline 1993 & $342,540.50$ & 103326.5 & 3731.7 & 120871.4 & 81456.3 & 445704.7 & 57.2 \\
\hline 1994 & $345,228.50$ & 103326.5 & 3350.0 & 118691.7 & 97056.6 & 449580.5 & 57.0 \\
\hline 1995 & $352,646.20$ & 103326.5 & 3170.0 & 121851.7 & 97042.0 & 521721.2 & 72.8 \\
\hline 1996 & $367,218.10$ & 103326.5 & 2960.0 & 240347.6 & 102630.0 & 464948.0 & 29.3 \\
\hline 1997 & $377,830.80$ & 221801.5 & 2840.0 & 137227.6 & 96199.0 & 462514.8 & 8.5 \\
\hline 1998 & $388,468.10$ & 221801.5 & 2680.0 & 182300.1 & 93214.0 & 503203.8 & 10.0 \\
\hline 1999 & $393,107.20$ & 361758.4 & 2440.0 & 433048.2 & 361194.9 & 2073292.0 & 6.6 \\
\hline 2000 & $412,332.00$ & 465535.7 & 2110.0 & 432718.2 & 379043.0 & 2544102.0 & 6.9 \\
\hline 2001 & $431,783.10$ & 584535.8 & 1830.0 & 432438.2 & 313504.7 & 2704459.0 & 18.9 \\
\hline 2002 & $451,785.60$ & 733762.5 & 1630.0 & 432238.2 & 375700.1 & 3403788.0 & 12.9 \\
\hline 2003 & $495,007.10$ & 825050.0 & 1470.0 & 432070.0 & 413877.7 & 3933437.0 & 14.0 \\
\hline 2004 & $527,576.00$ & 871577.0 & 1250.0 & 426188.2 & 384248.7 & 196155.5 & 15.0 \\
\hline 2005 & $561,931.40$ & 854828.4 & 980.0 & 420248.2 & 330654.4 & 2218349.0 & 17.9 \\
\hline 2006 & $595,821.61$ & 695000.0 & 720.0 & 414318.2 & 332219.2 & 0.0 & 8.2 \\
\hline 2007 & $634,656.60$ & 574929.4 & 620.0 & 408548.2 & 360427.6 & 0.0 & 5.4 \\
\hline
\end{tabular}

CBN statistical bulletin

public debts do result into increase in aggregate money supply and this causes an addition to demand and upward pressure on prices.

Also, consumption oriented debt can exert inflationary pressure on the economy. Therefore, from the mix of selected variables the empirical model for the analysis of the impact of debt financing options on economic growth in Nigeria between a decade after independence and 2007 fiscal year is specified as:

$$
\begin{aligned}
\operatorname{LRGDP}_{\mathrm{t}}= & \eta_{0}+\eta_{1} \mathrm{LTB}_{\mathrm{t}}+\eta_{2} \mathrm{LDEV}_{\mathrm{t}}+\eta_{3} \mathrm{LTCB}_{\mathrm{t}}+ \\
& \eta_{4} \mathrm{LMULT}_{\mathrm{t}}+\eta_{5} \mathrm{LCLUB}_{\mathrm{t}}+\eta_{6} \mathrm{LINF}_{\mathrm{t}}+\mathrm{u}_{\mathrm{t}} \ldots \ldots \ldots \ldots
\end{aligned}
$$

Where:

$$
\begin{aligned}
\eta_{0}= & \text { The intercept } \\
\eta_{1-6}= & \text { The slope or parameters for the debt financing mix } \\
& \text { and inflation rate } \\
\mathrm{u}= & \text { The error term and all the incorporated variables } \\
& \text { are loglinearized to avoid multicollinearity }
\end{aligned}
$$

The time series data for the incorporated variables from 1970-2007 are sourced from the Central Bank of Nigeria (CBN) Statistical Bulletin for several issues. The time series properties of the variables are examined through the use of Augmented Dickey Fuller (ADF) unit root test based on the following system of equations:

\section{Intercept:}

$$
\Delta \mathrm{X}_{\mathrm{t}}=\alpha_{0}+\alpha_{1} \mathrm{X}_{\mathrm{t}-1}+\sum_{\mathrm{i}=1}^{\mathrm{n}} \phi_{\mathrm{i}} \Delta \mathrm{X}_{\mathrm{t}-\mathrm{i}}+\omega_{\mathrm{t}}
$$

Trend:

$$
\Delta \mathrm{X}_{\mathrm{t}}=\alpha_{0}+\alpha_{1} \mathrm{X}_{\mathrm{t}-1}+\alpha_{2} \mathrm{t}+\sum_{\mathrm{i}=1}^{\mathrm{n}} \phi_{\mathrm{i}} \Delta \mathrm{X}_{\mathrm{t}-\mathrm{i}}+\omega_{\mathrm{t}}
$$

Where:

$\omega_{\mathrm{t}}=$ The residual term

$\mathrm{X}_{\mathrm{t}}=$ The time series variable

Also, the long-run interaction and behaviour between selected debt options and real gross domestic product 
that measures the growth rate of the economy is examined using the Augmented Engle-Granger (AEG) co-integration test.

\section{RESULTS AND DISCUSSION}

In examining the structure, distribution and trend patterns of the incorporated time series variables in model 1, the Augmented Dickey Fuller (ADF) unit root test was used. The test result is shown in Table 2.

The results reveal that Real Gross Domestic Product (RGDP), Treasury Bill (TB), Development stocks (DEV), Treasury Certificate and Bond (TCB), Multilateral debt (MULT) and Inflation rate (INF) are found to accept the null hypothesis of no stationary at level for both intercept and linear trend and this implies that the time series variables means and variance systematically vary over time.

But at first difference, the series are structurally stable in mean and variance and this implies that all the incorporated time series variables are stationary at first difference. In other words, they are integrated of order of one. From the entire considered variable in this analysis, it's only time series data on debt from international lending clubs (CLUB) found explosive at levels and first difference for both intercept and linear trend test models. This implies that the series is off consistency i.e., it's neither stable nor consistent in trend.

For the essence of other tests, like co-integration test we assume that all the incorporated time series variables in model 1 are integrated of order one i.e., stationary at first difference. In establishing the long-run relationship between real output and debt financing mix in Nigeria, the Augmented Engle-Granger (AEG) co-integration test is employed.

The test requires examining the structural distribution pattern of the residual term (u) generated from the specified model 1 after estimating. This is to know whether the linear combination of all the time series variables resulted into stationarity series i.e., the error term series is stationary at level without differencing like other variables to be stationary.

The co-integration test result shown in Table 3 revealed that the error term generated from model 1 is stationary at level for both intercept and linear trend test models. This implicates that the incorporated time series variables in model 1 are co-integrated and there exist long-run relationship between economic growth and adopted debt financing options in Nigeria from 1970-2007. The co-integrating regression result is shown in Table 4.
Table 2: ADF unit root test results

\begin{tabular}{llll}
\hline & ADF Tau statistics & & \\
Variables & - & & \\
\hline LRGDP & $-4.133^{*}(1)$ & Trend & Order \\
LTB & $-4.064^{*}(1)$ & $-4.674^{*}(1)$ & 1 \\
LDEV & $-3.258^{* *}(4)$ & $-128^{* *}(1)$ & 1 \\
LTCB & $-5.450^{*}(1)$ & $-4.464^{*}(1)$ & 1 \\
LMULT & $-3.597^{* *}(1)$ & $-5.485^{*}(1)$ & 1 \\
LCLUB & $3.643(1)$ & $-3.605^{* *}(1)$ & 1 \\
LINF & $-6.653^{*}(1)$ & $3.004(1)$ & EXP \\
\hline Sigican & $-6.693^{*}(1)$ & 1 \\
\hline
\end{tabular}

Significant at $(*)-1 \%$ and $\left({ }^{* *}\right)-5 \%$ McKinnon critical values. EXP means the time series variables is explosive. The values in parenthesis is the number of lag used for the test which is based on the minimum AIC and SIC

Table 3: AEG co-integration result

\begin{tabular}{lccc}
\hline Residual & Tau-Stat & Lag & Prob. \\
\hline Intercept & $-3.425^{*}$ & 1 & 0.0165 \\
Trend & $-3.900^{*}$ & 0 & 0.0220 \\
\hline
\end{tabular}

Significant at $\left(^{*}\right)-5 \%$ McKinnon critical values

Table 4: AEG co-integrating regression results ${ }^{1}$ of dependent variable LRGDP by least square method taking sample in 1970-2007

\begin{tabular}{lccc}
\hline Variables & Values & SE & Prob. \\
\hline C & 1.266 & 0.305 & 0.000 \\
LTB & -0.052 & 0.108 & 0.633 \\
LDEV & 0.772 & 0.092 & 0.000 \\
LTCB & 0.274 & 0.098 & 0.009 \\
LMULT & 0.207 & 0.087 & 0.023 \\
LCLUB & -0.074 & 0.022 & 0.003 \\
INF & -0.046 & 0.086 & 0.600 \\
\hline
\end{tabular}

$\mathrm{R}^{2}=0.94 ;$ Adjusted $\mathrm{R}^{2}=0.928 ;$ F-Statistic $=80.932 ;$ Prob (F-statistic) $=$ 0.0000 ; Durbin-Watson stat $=1.207 ;{ }^{1}$ Extracted from the E-View 5.1 output

The co-integrated regression results reveled that the formulated empirical model for this analysis is structural stable and the selected debt financing options and inflation rate accounted for over $93 \%$ for variation in Real Gross Domestic Product (RGDP) between the review periods based on the strength of the F-statistic and adjusted $R^{2}$ results, respectively.

\section{CONCLUSION}

The foregoing analysis showed that in the long-run Development stocks (DEV), Treasury Certificate and Bond (TCB) and Multilateral debt (MULT) are the best debt financing mix to propel the development level of the Nigerian economy in providing infrastructure facilities and undertaken developmental projects that will enhance the standard of living of the citizens in crease the national outputs and aid the achievements of other target macroeconomic objectives of the government. Sourcing for financing from international institutions like Paris and London Club should be avoided at all cost as because of the negative externalities exerting on the economy. Although, the federal government has realized the implications of sourcing for debt finance from 
international clubs since 2006 fiscal year because no such funds have been sourced from the clubs since 2006-2008 fiscal year. The study likewise revealed that Treasury Bill (TB) has not been an economic friendly debt financing option in Nigeria because of its negative impact on economic growth even though the effect was not significant. Therefore, much reliance must not be placed on Treasury Bill (TB) as an option for developmental financing.

\section{RECOMMENDATIONS}

Public debts should be well controlled as result of the possibility of increasing the aggregate money supply which might exert inflationary pressure on the entire economy especially if the debt is consumption oriented rather being used for productivity purposes to offset the obstinate problem of inflation.

\section{REFERENCES}

Ariyo, A., 1999. Appropriateness of development financing mix of Sub-Saharan African economies: Evidence from Nigeria. J. Econ. Soc. Stud., 41: $159-173$.

Ariyo, A., 2006. Development Financing of Underdevelopment. Faculty of the Social Sciences, University of Ibadan, Nigeria.

Oyejide, T.A., 1999. Taking stock of sustainable development finance in Sub-Saharan Africa. Proceedings of the Fifth Expert Group Meeting on Financial Issues of Agenda 21, Dec. 1-4, Nairobi, Kenya, pp: 1-12.

Taylor, L.S., 1997. Foreign resource flows and developing countries growth. Proceedings of the UNU-WIDER Conference on Medium-Term Development Strategy, Stockham.

World Bank, 2001. Global Development Finance. The World Bank, Washington, DC. USA. 